\title{
Keberhasilan Terapi Kombinasi Menggunakan Metotreksat Injeksi dan Siklosporin pada Psoriasis Pustulosa Generalisata
}

\author{
Oki Suwarsa, Nadilla Carissa Devi, Miranti Pangastuti, Endang Sutedja, Hartati Purbo Dharmadji \\ Departemen Ilmu Kesehatan Kulit dan Kelamin Fakultas Kedokteran Universitas Padjadjaran \\ Rumah Sakit Umum Pusat Dr. Hasan Sadikin Bandung
}

\begin{abstract}
Abstrak
Psoriasis pustulosa generalisata (PPG) adalah bentuk khusus dari psoriasis yang bersifat akut dan berat. Etiologi yang belum diketahui secara pasti menyebabkan pengobatan PPG masih menjadi suatu tantangan. Terapi kombinasi dapat diberikan pada PPG yang berat maupun yang tidak memberikan respons terhadap terapi sistemik tunggal, selain itu terapi kombinasi juga dapat meningkatkan efektivitas dari obat tunggal. Dilaporkan satu kasus PPG pada seorang wanita yang diterapi dengan menggunakan kombinasi metotreksat (MTX) injeksi dan siklosporin. Dari anamnesis dan pemeriksaan fisis didapatkan pustula berkelompok pada dasar makula eritem yang bergabung membentuk lake of pus, disertai gejala sistemik demam dan leukositosis. Keluhan tersebut sudah berulang sejak 13 tahun yang lalu. Pasien diberikan terapi kombinasi injeksi MTX dan siklosporin. Pustula pada pasien menghilang setelah tujuh hari pemberian obat. Terapi kombinasi dengan MTX injeksi dan siklosporin ini baru pertama kali dilakukan 19 Mei-26 Mei 2017 di Departemen Ilmu Kesehatan Kulit dan Kelamin Fakultas Kedokteran Universitas Padjadjaran/Rumah Sakit Umum Pusat Dr. Hasan Sadikin Bandung dan memberikan hasil yang baik. [MKB. 2017;49(3):208-12]
\end{abstract}

Kata kunci: Metotreksat, metotreksat injeksi, psoriasis pustulosa generalisata, siklosporin

\section{Succesful Treatment of Generalized Pustular Psoriasis with a Combination of Methotrexate Injection and Cyclosporine}

\begin{abstract}
Generalized pustular psoriasis (GPP) is a special form of acute and severe psoriasis. The definite etiology of GPP remains a challenge. Combination therapy may be given to severe GPP or GPP that does not respond to a single systemic therapy sincecombination therapy may also improve the effectiveness of a monotherapy drug. A GPP case was reported in a woman treated with a combination of methotrexate (MTX) and cyclosporine. From anamnesis and physical examination it was revealed that there were clustered pustules on the base of erythematous macules that form a lake of pus accompanied by systemic symptoms of fever and leukocytosis. This was a recurrent complaint since 13 years ago. Patients were given combination therapy of MTX injection and cyclosporine. Pustules disappeared after seven days of drug administration. This case was the first combination therapy with MTX injection and cyclosporine used during the period of 19 May to 26 May 2017 at the Department of Dermatology and Venereology Universitas Padjadjaran/Dr. Hasan Sadikin General Hospital Bandung, resulting in good results. [MKB. 2017;49(3):208-12]
\end{abstract}

Key words: Cyclosporine, generalized pustular psoriasis, methotrexate, methotrexate injection

Korespondensi: Dr. Oki Suwarsa, dr., Sp KK(K), M.Kes., Departemen Ilmu Kesehatan Kulit dan Kelamin Fakultas Kedokteran Universitas Padjadjaran/Rumah Sakit Umum Pusat Dr. Hasan Sadikin Bandung, E-mail: okispkk@yahoo.co.id 


\section{Pendahuluan}

Psoriasis pustulosa generalisata atau lebih dikenal PPG merupakan salah satu varian psoriasis yang jarang terjadi, bersifat akut, dan dapat mengancam jiwa. ${ }^{1}$ Gejala khas PPG adalah pustula steril dan terdapat terutama pada batang tubuh dengan disertai gejala sistemik seperti demam yang timbul secara mendadak disertai dengan menggigil. ${ }^{2}$

Penanganan PPG umumnya membutuhkan terapi topikal, sistemik, serta terapi suportif untuk memperbaiki keadaan umum pada pasien serta menyingkirkan faktor-faktor pencetus yang dicurigai. $^{3}$ Terdapat beberapa pilihan terapi sistemik untuk PPG, yaitu siklosporin, metotreksat (MTX), asitretin, dan juga fumaric acid ester. ${ }^{2,4}$ Pada kasus yang berat dan tidak memperlihatkan perbaikan sesudah dilakukan terapitunggal,dapatdipertimbangkan pemberian terapi kombinasi. ${ }^{5}$ Terapi kombinasi mampu meningkatkan efektivitas dan mengurangi efek samping obat. ${ }^{2,5}$ Terdapat suatu penelitian yang melaporkan terapi kombinasi MTX dan beberapa obat, di antaranya MTX dengan siklosporin dan memberikan hasil yang baik tanpa efek samping yang menetap. ${ }^{5}$

\section{Laporan Kasus}

Dilaporkan seorang perempuan, usia 47 tahun, menikah, ibu rumah tangga, pendidikan terakhir Sekolah Dasar (SD), suku Sunda, agama Islam, dirawat di Ruang Amarilis RSUP Dr. Hasan Sadikin (RSHS) Bandung mulai tanggal 19 Mei 2017 sampai dengan 26 Mei 2017 dengan keluhan utama berupa bercak kemerahan dan beruntus-beruntus berisi nanah pada hampir seluruh tubuh yang terasa gatal dan nyeri.

Pasien pertama kali mengalami keluhan kurang lebih 13 tahun yang lalu berupa pustula dengan dasar makula eritemaa pada hampir seluruh tubuh. Riwayat dirawat di rumah sakit karena keluhan serupa sebanyak tiga kali dan mendapatkan terapi MTX per oral. Pada bulan Februari 2017 pasien dirawat kembali di RSHS dengan keluhan beruntus berisi nanah yang timbul pada hampir seluruh tubuh, kemudian pasien diberikan obat siklosporin 2x100mg. Pasien dirawat selama 8 hari dan pulang dengan perbaikan. Pasien kontrol kembali ke Poliklinik Imunoalergi RSHS serta mendapatkan terapi siklosporin 2x100mg, namun karena keluhan kulit mengalami perbaikan, pasien tidak kontrol dan menghentikan sendiri siklosporin sejak kurang lebih satu bulan sebelum masuk rumah sakit.

Sejak 4 hari sebelum masuk rumah sakit pustula yang telah ada sebelumnya pada seluruh tubuh semakin bertambah dan disertai dengan demam dan menggigil sehingga pasien berobat ke Instalasi Gawat Darurat (IGD) RSHS. Riwayat infeksi saluran pernafasan atas sebelum kelainan kulit muncul diakui, sedangkan riwayat karies gigi disangkal oleh pasien.

Pada pemeriksaan fisik didapatkan hipertensi, suhu febris, dan status gizi overweight. Pada status generalis tidak ditemukannya kelainan. Pada status dermatologikus telah ditemukan lesi berupa makula eritema, pustula dengan dasar makula eritema, skuama, dan beberapa pustula membentuk lake of pus (Gambar 1). Pemeriksaan laboratorium ditemukan anemia, leukositosis, dan hipokalemia. Pada pemeriksaan histopatologi sebelumnya didapatkan kepsoriasis pustulosa.

Pasien diterapi dengan topikal kompres terbuka mempergunakan larutan $\mathrm{NaCl}$ 0,9\% dua kali sehari pada pustula dan krim desoksimetason 0,25\% dioleskan dua kali sehari pada makula eritema. Terapi sistemik yang diberikan tersebut adalah siklosporin $2 \times 100 \mathrm{mg}$ per oral, injeksi metotreksat 3x5 mg intramuskular per minggu dengan interval 12 jam setiap pemberian, dan intravenous fluid drip (IVFD) $\mathrm{NaCl}$ 0,9\% 1.500 cc/24 jam.

\section{Hasil}

Pada pengamatan hari ketiga kelainan kulit baru berupa pustula timbul kembali pada paha kiri dan punggung, dan pasien diberikan terapi tambahan, yaitu asam folat $1 \times 5 \mathrm{mg}$ per oral dan Calos $^{\circledR} 3$ x 500 mg per oral. Pada pengamatan hari ketujuh, kelainan kulit baru sudah tidak timbul dan rasa nyeri berkurang. Pada pengamatan hari ke-16 pasien kontrol ke Poliklinik Ilmu Kesehatan Kulit dan Kelamin, pasien mengeluhkan kelainan kulit baru berupa pustula timbul kembali di paha kanan dan kiri. Pasien diberikan terapi topikal krim desoksimetason 0,25\% 2 kali sehari pada makula eritema dan kompres terbuka dengan larutan $\mathrm{NaCl} 0,9 \%$ pada pustula 2 kali sehari. Terapi sistemik siklosporin 2x100 mg per oral, injeksi metotreksat $15 \mathrm{mg}$ subkutan serta asam folat $1 \times 5 \mathrm{mg}$ per oral. Pada pengamatan hari ke-23, tidak ditemukan pustula dan sebagian besar makula eritemaa telah menjadi makula hiperpigmentasi (Gambar 2). 


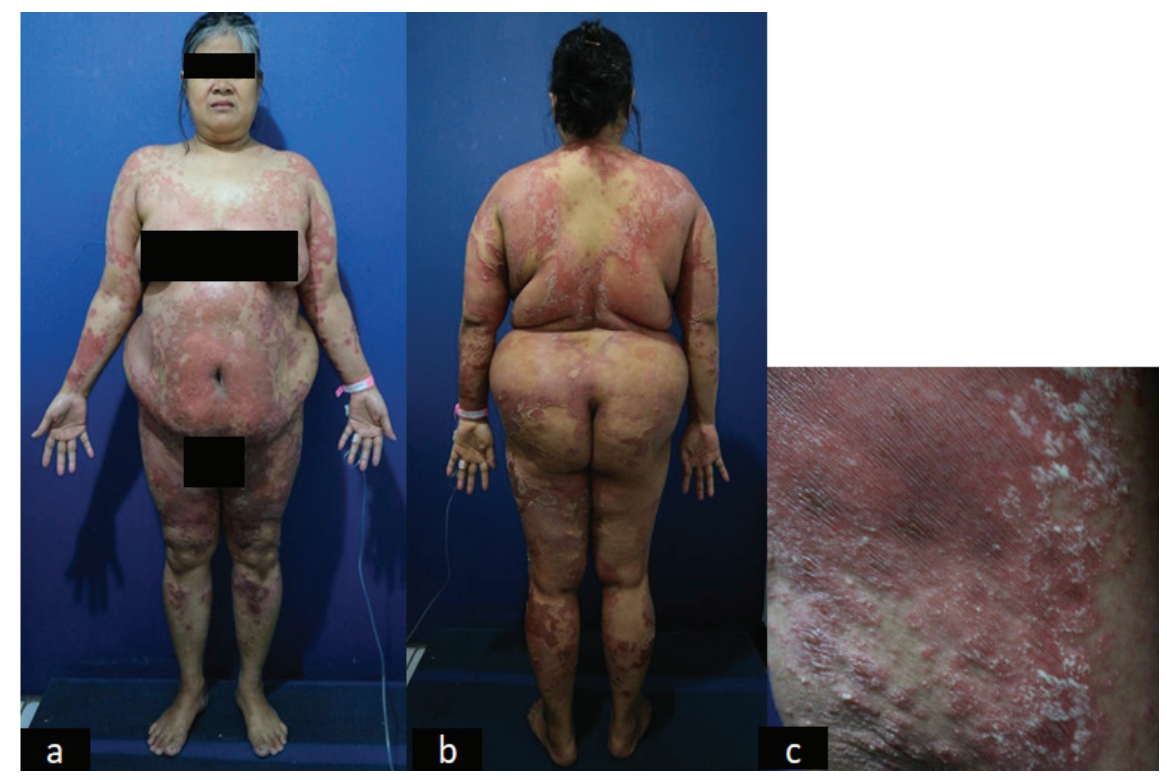

Gambar 1 Gambaran Klinis Sebelum Terapi. a. Tampak Depan; b. Tampak Belakang; c. Pustula yang Sebagian Membentuk Lake of Pus dengan Dasar Makula Eritema

\section{Pembahasan}

Psoriasis pustulosa generalisata adalah suatu bentuk psoriasis yang berat jarang terjadi dan mengancam jiwa. ${ }^{2}$ Etiologi timbulnya PPG masih belum diketahui secara jelas. ${ }^{6}$ Infeksi merupakan salah satu yang diperkirakan sebagai pencetus timbulnya PPG, infeksi tersering adalah infeksi saluran pernafasan atas, gigi, serta infeksi yang disebabkan oleh Streptococcus Grup A dan
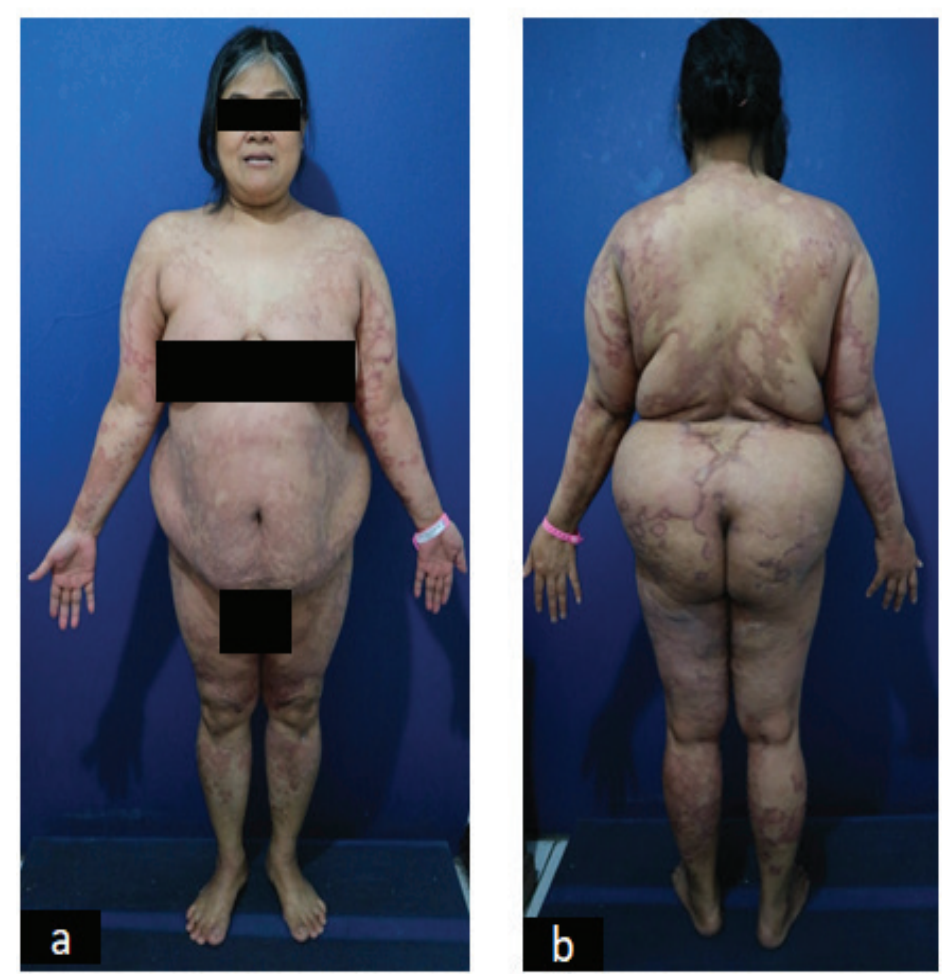

Gambar 2 Gambaran Klinis 23 Hari Setelah Terapi a. Tampak Depan; b. Tampak Belakang 


\section{Staphylococcus. ${ }^{7}$}

Psoriasis pustulosa generalisata umumnya diawali dengan gejala demam serta malaise beberapa hari sebelum timbul kelainan kulit., ${ }^{2,3}$ Kemudian akan timbul pustula steril dengan diameter 2-3 mm dengan dasar makula eritema. ${ }^{2,8}$ Pustula tersebut kemudian bersatu, ${ }^{9}$ membentuk gambaran lake of pus yang selanjutnya akan mengalami deskuamasi. ${ }^{9,10}$ dan diikuti timbulnya suatu pustula baru beberapa hari setelahnya. ${ }^{10}$ Pemeriksaan laboratorium pada pasien PPG dapat ditemukan leukositosis, hipokalsemia, hipoalbuminemia, dan peningkatan laju endap darah (LED). ${ }^{9,10}$

Psoriasis pustulosa generalisata tersebut juga membutuhkan terapi yang efektif untuk dapat mencegah komplikasi. ${ }^{2}$ Terdapat beberapa pilihan pengobatan sistemik yang merupakan lini pertama pada pengobatan PPG, yaitu MTX, siklosporin dan asitretin. ${ }^{11}$ Terapi kombinasi dapat dipertimbangkan pada PPG kasus yang berat atau yang tidak menunjukkan perbaikan setelah terapi tunggal. ${ }^{5}$ Terapi kombinasi juga diharapkan mampu meningkatkan efektivitas terapi dan mengurangi efek samping yang dapat ditimbulkan obat-obat monoterapi dalam jangka waktu yang lama. ${ }^{2,12}$ Salah satu kombinasi yang dapat digunakan adalah kombinasi MTX dan siklosporin. ${ }^{13,14}$ Penelitian yang dilakukan oleh Mohanan dkk. ${ }^{13}$ terhadap 18 pasien dengan psoriasis, 14 pasien telah mendapatkan terapi kombinasi selama kurang dari tiga bulan, dan empat pasien mendapatkan terapi kombinasi MTX dan siklosporin selama lebih dari tiga bulan Dari keseluruhan 18 pasien tersebut didapatkan hasil yang cukup baik tanpa efek samping yang ireversibel.

Metotreksat adalah obat derivat aminopterin analog asam folat yang memiliki efek antiinflamasi, antiproliferasi, dan imunosupresi. ${ }^{12}$ Pemberian MTX dapat secara oral, intramuskular, subkutan, ${ }^{4}$ dan juga intravena. ${ }^{12,15}$ MTX dapat diberikan terhadap semua jenis psoriasis. ${ }^{12}$ Mekanisme kerja MTX adalah menghambat enzim dehidrofolat reduktase dalam proses pembentukan purin dan pirimidin. ${ }^{12,15}$ Enzim dihidrofolat reduktase berguna untuk mengubah asam dihidrofolat menjadi asam tetrahidrofolat dan juga menghambat enzim timidilate sintetase yang akan menyebabkan pengurangan jumlah timidilat dan folat yang merupakan komponen purin dan pirimidin yang dibutuhkan saat proses sintesis deoxyribonucleic acid (DNA). ${ }^{12}$ Sintesis DNA yang dihambat akan menyebabkan apoptosis dari sel $\mathrm{T}$ yang telah teraktivasi ${ }^{12,15}$ serta menghambat kemotaksis neutrofil. ${ }^{12}$
Dosis awal MTX yang umum dipergunakan adalah 7,5 mg, $15 \mathrm{mg}$, dan $5 \mathrm{mg}$ merupakan dosis awal yang kedua dan ketiga tersering untuk digunakan. ${ }^{16}$ Menurut penelitian yang dilakukan Robinson. ${ }^{4}$ MTX dapat diberikan pada PPG dengan dosis berkisar 5-15 mg per minggu bergantung keparahan penyakit pasien dan dapat ditingkatan 2,5 mg setiap minggu hingga didapatkan respons yang diharapkan tanpa melebihi dosis maksimal $25 \mathrm{mg}$ per minggu.

Siklosporin merupakan obat dengan golongan inhibitor kalsineurin yang bersifat hidrofobik dan lipofilik. Siklosporin akan menghambat aktivasi sel $\mathrm{T}$ yang dicetuskan oleh presentasi antigen pada sel T. Presentasi antigen pada $T$ cell receptor (TCR) akan meningkatkan kalsium intrasel, kalsium bebas akan berikatan dengan kalmodulin, kompleks tersebut akan menempel pada kalsineurin. Kompleks CyA yang merupakan reseptor yang memiliki afinitas tinggi terhadap siklosporin akan berikatan dengan kalsineurin dan akan menghambat defosforilasi nuclear factor of activated $T$ cell (NFATc) sehingga akan menghambat produksi sitokin, kemokin, dan faktor pertumbuhan. ${ }^{17}$ Dosis siklosporin adalah 2,5-5 mg/kgbb/hari, dapat ditingkatkan 0,5-1 $\mathrm{mg} / \mathrm{kgbb} /$ hari setiap 2 sampai 4 minggu. ${ }^{4,17}$ Siklosporin mempunyai efek terhadap tekanan darah dan nefrotoksis, sehingga perlu dilakukan penapisan awal berupa pemeriksaan tekanan darah dan kreatinin serum. Apabila terdapat peningkatan kreatinin serum lebih dari atau sama dengan $30 \%$ dari nilai baseline saat pasien mengonsumsi siklosporin maka dosis harus diturunkan..$^{17,18}$

Simpulan, kombinasi terapi MTX injeksi dan siklosporin dapat diberikan pada kasus PPG yang berat, dan memiliki efektivitas yang baik dengan efek samping yang minimal.

\section{Daftar Pustaka}

1. Jin H, Cho HH, Kim WJ, Mun JH, Song M, Kim HS, dkk. Clinical features and course of generalized pustular psoriasis in Korea. J Dermatol. 2015;42(7):674-8.

2. Gudjonsson JE, Elder JT. Psoriasis. Dalam: Goldsmith LA, Katz SI, Gilchrest BA, Paller AS, Leffell DJ, Wolff K, penyuning. Fitzpatrick's dermatology in general medicine. Edisi ke-8. New York: Mc Graw Hill; 2012. hlm. 197-231.

3. Van de Kerkhof PC, Schalkwijk J. Psoriasis. Dalam: Bolognia JL, Jorizzo JL, Rapini R, penyunting. Dermatology. Edisi ke-2. New York: Elsevier; 2008. hlm. 115-35. 
4. Robinson A, Voorhees AS, Hsu S, Korman NJ, Lebwohl MG, Bebo BF, dkk. Treatment of pustular psoriasis from the medical board of the national psoriasis foundation. J Am Acad Dermatol. 2012;67(2):279-88.

5. Jensen P, Skov L, Zachariae C. Systemic combination treatment for psoriasis: a review. Acta Derm Venereol. 2010; 90(4):341-9.

6. Razvi F, Haneef NS, Sri Teja V, Bang R, Hasnath FU. Generalized pustular psoriasis of pregnancy. J Med Allied Sci. 2015;5(2):513.

7. Malathi M, Thappa DM. Pustular psoriasis in children- a review. Nepal J Dermatol Venereol Leprol. 2012;10(1):1-10.

8. Benjegerdes KE, Hyde K, Kivelevitch D, Mansouri B. Pustular psoriasis: pathophysiology and current treatment perspectives. Psoriasis: Targets Ther. 2016;6: 131-44.

9. Varman KM, Namias N, Schulman CI, Pizano LR. Acute generalized pustular psoriasis, von Zumbusch type, treated in the burn unit. Burns. 2014;40(4):e35-9.

10. Wang Q, Liu W, Zhang L. Clinical features of von Zumbusch type of generalized pustular psoriasis in children: a retrospective study of 26 patients in southwestern China. An Bras Dermatol. 2017;92(3):319-22.

11. Choon SE, Lai NM, Mohammad NA, Nanu NM, Tey KE, Chew SF. Clinical profile, morbidity, and outcome of adult-onset generalized pustular psoriasis: analysis of 102 cases seen in a tertiary hospital in Johor, Malaysia. Int J Dermatol. 2014;53(6):676-84.
12. Operacz MC, Przytocka AS. The possibilities and principles of methotrexate treatment of psoriasis-the updated knowledge. Postep Derm Alergol. 2014;31(6):392-400.

13. Mohanan S, Ramassamy S, Chandrashekar L, Thappa DM. A retrospective analysis of combination methotrexate-cyclosporine therapy in moderate-severe psoriasis. J Dermatolog Treat. 2014;25(1):50-3.

14. Balighi K, Zahra GS, Azadeh G, Pardis $\mathrm{H}$, Ehsan S, Arghavan A. Assessment of the therapeutic aspect of systemic non-biologic anti-psoriatic treatment modalities used in combination with methotrexate. Indian J Dermatol. 2016;61(1):118-25.

15. Dogra S, Mahajan R Systemic methotrexate therapy for psoriasis: past, present and future. Clin Exp Dermatol. 2013;38(6):57388.

16. Gyulai R, Bagot M, Griffiths CEM, Luger T, Naldi $\mathrm{L}$, dkk. Current practice of methotrexate use for psoriasis: results of a worldwide survey among dermatologists. J Eur Acad Dermatol Venereol. 2015;29(2):224-31.

17. Callen JP. Kulp-Shorten CL. Methotrexate. Dalam: Wolverton SE, penyunting. Comprehensive dermatologic drug therapy. Indianapolis: Elsevier Saunders; 2013. hlm. 169-81.

18. Menter A, Korman NJ, Elmets CA, Feldman SR, Gelfand JM, Gordon KB, dkk. Guidelines of care for the management of psoriasis and psoriatic arthritis: section 4. Guidelines of care for the management and treatment of psoriasis with traditional systemic agents. J Am Acad Dermatol. 2009;61(3):451-85. 